\title{
The Reactions of Common Chemical Fertilizers in An Ultisol and Their Effects on Cowpea Performance
}

\author{
Oyeyiola Yetunde Bunmi ${ }^{1 *}$ and Omueti John Ajayi ${ }^{2}$ \\ ${ }^{I}$ Department of Crop Production and Soil Science, Ladoke Akintola University of Technology, \\ Ogbomoso, Oyo State Nigeria, Nigeria, e-mail: yboyeyiola@lautech.edu.ng \\ ${ }^{2}$ Department of Agronomy, University of Ibadan, Nigeria
}

Received October 26, 2018; Revised December 12, 2018; Accepted 14 January 2019

\begin{abstract}
Chemical fertilizers (CF) are the major input on arable farms in Nigeria. Current increasing rate of nutrient depletion in CF treated soils calls for the need to study their reactions in soils. To achieve this, three CF based treatments, namely NPK 15:15:15 applied at $40 \mathrm{~kg} \mathrm{P}_{2} \mathrm{O}_{5}$ ha $^{-1}$, Urea applied at $20 \mathrm{~kg} \mathrm{~N}$ ha $^{-1}$ mixed with Single superphosphate at $40 \mathrm{~kg} \mathrm{P}_{2} \mathrm{O}_{5} \mathrm{ha}^{-1}$, and single superphosphate at $40 \mathrm{~kg} \mathrm{P}_{2} \mathrm{O}_{5} \mathrm{ha}^{-1}$ mixed with Gliricidia sepium leaves at $20 \mathrm{~kg} \mathrm{~N} \mathrm{ha}^{-1}$ were studied. Sole lime $\left(\mathrm{CaCO}_{3}\right)$ at $1 \mathrm{Mg} \mathrm{ha}^{-1}$ and a plot that received no amendment were compared. Cowpea was grown for two consecutive cropping seasons in 2012 and 2013 on the treated fields. The results indicated that CF reduced soil pH from initial 4.8 to 4.0. The NPK 15:15:15 fertilizer was the most severe of the CF tested, removing up to $133 \%$ alkalinity from the soil relative to lime. The NPK 15:15:15 reduced calcium saturation (from $25 \%$ to $21 \%$ ) and magnesium saturation (from $12 \%$ to $8.3 \%$ ) and increased acidity saturation (from $53 \%$ to $66 \%$ ) with significant reductions in organic carbon content (from $13.2 \mathrm{~g} \mathrm{~kg}^{-1}$ to $11.0 \mathrm{~g} \mathrm{~kg}^{-1}$ ). Precaution including co-application of $\mathrm{CF}$ with organic materials such as Gliricidia sepium leaves can benefit for the soils.
\end{abstract}

Keywords: Acidification efficiency, base saturation, exchangeable aluminum, NPK 15:15:15 fertilizer, Single Super Phosphate

\begin{abstract}
ABSTRAK
Pupuk kimia merupakan input utama pada lahan pertanian di Nigeria. Peningkatan laju kehilangan unsur hara pada tanah-tanah pertanian yang diaplikasikan pupuk kimia telah memicu pentingnya studi tentang reaksi pupuk kimia di dalam tanah. Untuk mencapai tujuan tersebut, tiga perlakuan yang menggunakan pupuk kimia, yaitu NPK 15:15:15 dengan dosis $40 \mathrm{~kg} \mathrm{P}_{2} \mathrm{O}_{5}$ ha, Urea $20 \mathrm{~kg} \mathrm{~N}^{-1}$ yang dicampurkan dengan Single Superphosphate $40 \mathrm{~kg} \mathrm{P}_{2} \mathrm{O}_{5} \mathrm{ha}^{-1}$, dan Single Superphosphate $40 \mathrm{~kg} \mathrm{P}_{2} \mathrm{O}_{5} \mathrm{ha}^{-1}$ yang dicampurkan dengan daun Gliricidia sepium $20 \mathrm{~kg} \mathrm{~N} \mathrm{ha}^{-1}$ dipelajari. Plot yang diaplikasikan kapur $\left(\mathrm{CaCO}_{3}\right) 1 \mathrm{Mg} \mathrm{ha}^{-1}$ dan plot tanpa perlakuan (kontrol) digunakan sebagai pembanding. Kacang tunggak ditanam pada lahan yang diberi perlakuan-pemupukan tersebut selama dua musim tanam berturut-turut pada tahun 2012 dan 2013. Hasil penelitian menunjukkan bahwa aplikasi pupuk kimia telah menurunkan $\mathrm{pH}$ tanah dari 4,8 menjadi 4,0. Pupuk NPK 15:15:15 memberikan efek yang paling nyata terhadap penurunan $\mathrm{pH}$ tanah, yaitu mampu menghilangkan hingga 133\% alkalinitas tanah dibandingkan dengan kapur. Aplikasi pupuk NPK 15:15:15 telah menurunkan kejenuhan kalsium (dari 25\% ke 21\%) dan kejenuhan magnesium (dari 12\% ke 8,3\%), dan meningkatkan kejenuhan kemasaman (dari 53\% ke 66\%) dengan penurunan kandungan

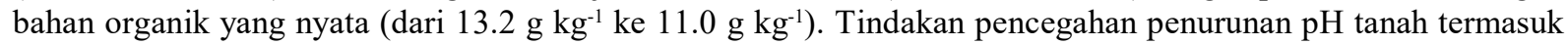
mengaplikasikan pupuk kimia bersama bahan organik seperti daun Gliricidia sepium dapat memberikan keuntungan bagi tanah-tanah pertanian.
\end{abstract}

Kata kunci: Aluminium dapat dipertukarkan, efisiensi pengasaman, kejenuhan basa, pupuk NPK 15:15:15, Single Superphosphate

J Trop Soils, Vol. 24, No. 1, 2019: 25-32

ISSN 0852-257X; E-ISSN 2086-6682 


\section{INTRODUCTION}

Since the advent of the green revolution, chemical fertilizers have become the major input in supplying one or more nutrients on arable farms in Nigeria as against shifting cultivation, bush fallowing and use of manures before their introduction in the early 1960s (Hamma and Ibrahim 2013). They have played notable role in increasing the world food production (FAO 2000). Nitrogenous fertilizer alone had contributed to substantial increases in crop yield (Geisseler and Scow 2014). Chemical fertilizers however have both beneficial and detrimental effects on the environment (FAO 2006).

The use of NPK 15:15:15 and urea is common among farmers in southwestern Nigeria. Subsidies given on these fertilizers by government encourages their increasing dosage usage. These fertilizers are at most time applied indiscriminately without recommendation from any soil testing procedures. Surprisingly, accompanying these chemical fertilizers with organic materials such as green manure, animal dung and compost are not the usual practice. This of course has contributed to yearly nutrient degradation and eventual crop yield reduction (Oyeyiola et al. 2015). As a result, many farmers have abandoned their nutrient degraded fields and this has affected the food security and life sustenance of the farmers and the populace at large.

Earlier works have shown that the application of chemical fertilizers increase soil acidification (Lungu and Dynoodt 2008; Oyeyiola et al. 2014), loss of soil organic matter (Amlinger et al. 2007) and occurrence of nutrient imbalance in tropical soils. Nevertheless, published data are few on the reactions and effects of chemical fertilizers on soil chemistry in southwestern Nigeria. Therefore, this work aimed at generating data on the effects of reactions of common chemical fertilizers on soil $\mathrm{pH}$, organic carbon, total nitrogen, available phosphorus and cation saturations as they affect cowpea yield performance in an acidic soil.

\section{MATERIALS AND METHODS}

\section{Description of the Experimental Site}

The study was conducted at the Teaching and Research farm of the Leventis School of Agriculture, Imo Ilesha $\left(07^{\circ} 36 " \mathrm{~N} 04^{\circ} 46^{\prime \prime} \mathrm{E}, 1368 \mathrm{ft}\right.$ above sea level). The site falls within a schist belt with rich alluvial deposits which form part of the Precambrian basement rock notable for clay rich weathered horizons (Oke et al. 2013). The soil is an Ultisol (Amusan and Ashaye 1991) classified as Itagunmodi at local soil series level (Smyth and Montgomery 1962). The soil is characterized by reddish colour and low base saturation (Smyth and Montgomery 1962). The area lies in the rain forest agroecological zone.

\section{Soil Sampling and Analysis}

A field with the size of $16 \mathrm{~m} \times 10 \mathrm{~m}$ was divided into three transverse plots. Soil samples were taken randomly from five spots in each plot with a depth of (0-20) $\mathrm{cm}$ using a soil auger. The soil samples were air dried, sieved by $2 \mathrm{~mm}$ and $0.5 \mathrm{~mm}$ mesh size sieves and composited in triplicate subjected to soil analysis. Particle size was determined by hydrometer method (Bouyoucos 1962). Soil pH was determined on a 1:2 (soil:water ratio) after 15 minutes equilibration period using a glass electrode calibrated in $\mathrm{pH}$ buffers 4, 7 and 9. Organic carbon was determined by the dichromate wet oxidation method as described by International Institute of Tropical Agriculture (1978). Total Nitrogen was determined by Micro-Kjeldahl method as described by Bremner (1982). Phosphorus was extracted with Bray P-1 solution and the $\mathrm{P}$ in the extract was determined by Molybdate blue colour method of Murphy and Riley (1962) on Spectronic 20. Exchangeable cations (Ca, $\mathrm{Mg}, \mathrm{K}$ and $\mathrm{Na}$ ) were extracted with $1 \mathrm{~N} \mathrm{NH}_{4} \mathrm{OAc}$ $\mathrm{pH} 7$ at a soil:solution ratio of $1: 10$ for 15 minutes. The concentrations of $\mathrm{Ca}$ and $\mathrm{Mg}$ were measured on the Atomic Absorption Spectrophotometer while those of $\mathrm{K}$ and $\mathrm{Na}$ were measured on the Flame Photometer. Exchangeable acidity was extracted with $1 \mathrm{~N} \mathrm{KCl}$ and titrated against $0.01 \mathrm{~N} \mathrm{NaOH}$. Exchangeable $\mathrm{Al}$ was determined by further titration of the same extract of $0.01 \mathrm{~N} \mathrm{HCl}$ as described by (McLean, 1965 and Cassio et al. 2003). The effective cation exchange capacity (ECEC) was obtained by the sum of the total exchangeable bases and total exchangeable acidity.

\section{Treatments and Experimental Design}

The field laid out into $2 \mathrm{~m} \times 2 \mathrm{~m}$ plots received three chemical fertilizer treatments, i.e. (1) NPK 15:15:15 applied at $40 \mathrm{~kg} \mathrm{P}_{2} \mathrm{O}_{5}$ ha $^{-1}$ (equivalent to 106 $\mathrm{g} 4 \mathrm{~m}^{-2}$ ), tagged as NPK; (2) Urea applied at $20 \mathrm{~kg} \mathrm{~N}$ $\mathrm{ha}^{-1}$ (equivalent to $17.7 \mathrm{~g} \mathrm{plot}^{-1}$ ) mixed with Single Supper Phosphate (SSP) applied at $40 \mathrm{~kg} \mathrm{P}_{2} \mathrm{O}_{5} \mathrm{ha}^{-1}$ (equivalent to $88.9 \mathrm{~g} \mathrm{plot}^{-1}$ ), tagged as Urea $+\mathrm{SSP}$; and (3) $\mathrm{SSP}$ at $40 \mathrm{~kg} \mathrm{P}_{2} \mathrm{O}_{5}$ ha $^{-1}$ (equivalent to $88.9 \mathrm{~g} \mathrm{plot}^{-}$ 1) mixed with Gliricidia sepium leaves at $20 \mathrm{~kg} \mathrm{~N}^{-} \mathrm{ha}^{-}$ ${ }^{1}$ (equivalent to $250 \mathrm{~g} \mathrm{plot}^{-1}$ ), tagged as SSP+GL. Plots that received only $\mathrm{CaCO}_{3}$ applied at $1 \mathrm{Mg} \mathrm{ha}^{-1}$ (equivalent to $400 \mathrm{~g} \mathrm{plot}^{-1}$ ) tagged as Lime, and an untreated plot tagged as $\mathrm{C}$ (control) were compared. 
Table 1. Physical and chemical properties of the soils used in the current study.

\begin{tabular}{ll}
\hline Parameters & Value \\
\hline $\mathrm{pH}($ water, 1:2) & 4.8 \\
Org. Carbon $\left(\mathrm{g} \mathrm{kg}^{-1}\right)$ & 13.2 \\
Total N $\left(\mathrm{g} \mathrm{kg}^{-1}\right)$ & 1.3 \\
Avail. P (Bray-1) $\left(\mathrm{mgkg}^{-1}\right)$ & 3.6 \\
Exchangeable Cations $\left(\mathrm{cmolkg}^{-1}\right)$ & \\
$\mathrm{Ca}$ & 0.98 \\
$\mathrm{Mg}$ & 0.48 \\
$\mathrm{~K}$ & 0.20 \\
$\mathrm{Na}$ & 0.20 \\
Ex. Acidity $\left(\mathrm{cmolkg}^{-1}\right)$ & 2.10 \\
ECEC $(\mathrm{cmolkg})$ & 3.96 \\
Particle size $\left(\mathrm{g} \mathrm{kg}^{-1}\right)$ & \\
Sand & 530 \\
Silt & 150 \\
Clay & 320 \\
& Sandy \\
Textural class & clay loam \\
\hline
\end{tabular}

All the treatments were laid out in a Randomized Complete Block Design with three replications. The same treatments were reapplied on the field during the second cropping in 2013 except that fresh Gliricidia sepium leaves were not added to the $\mathrm{SSP}+\mathrm{GL}$ plots. Cowpea (Ifebimpe variety) was used as the test crop.

\section{Data Collection}

During the two cropping seasons, post sowing soil samplings were done fortnightly for soil $\mathrm{pH}$ determination. Liming efficiency (LE) of individual treatment applied was estimated from the soil $\mathrm{pH}$ determined following a formula adopted by Anetor and Akinrinde (2007).

$$
\mathrm{LE}=\frac{\text { Soil } \mathrm{pH} \text { of CFTP }- \text { Soil } \mathrm{pH} \text { of CP }}{\text { Soil } \mathrm{pH} \text { of CLTP }- \text { Soil pH of CP }} \times 100 \%
$$

In which CFTP is chemical fertilizer treated plot; $\mathrm{CP}$ is control plot (without chemical fertilizer or lime); CLP is conventional lime treated plot.

The soil samples taken at harvesting (12 weeks after sowing (WAS)) were sampled for $\mathrm{pH}$, exchangeable bases, exchangeable acidity, ECEC, total nitrogen, organic carbon and available phosphorus measurements following procedures described earlier. Saturation percentages of base cations, base saturation, acidity, aluminum and hydrogen were estimated using the following formulae:

$$
\begin{aligned}
& \text { Ca saturation }(\%)=\frac{\text { Exchangeable } \mathrm{Ca}}{\text { ECEC }} \times 100 \% \\
& \mathrm{Mg} \text { saturation }(\%)=\frac{\text { Exchangeable } \mathrm{Mg}}{\text { ECEC }} \times 100 \% \\
& \text { K saturation }(\%)=\frac{\text { Exchangeable } \mathrm{K}}{\text { ECEC }} \times 100 \% \\
& \text { Base Saturation }(\%)=\frac{\text { Exchangeable bases }(\mathrm{Ca}+\mathrm{Mg}+\mathrm{K}+\mathrm{Na})}{\mathrm{ECEC}} \times 100 \% \\
& \text { Acidity Saturation }(\%)=\frac{\text { Exchangeable acidity }(\mathrm{H}+\mathrm{A} 1)}{\mathrm{ECEC}} \times 100 \% \\
& \text { Al saturation }(\%)=\frac{\text { Exchangeable } \mathrm{A} 1}{\text { ECEC }} \times 100 \% \\
& \mathrm{H} \text { saturation }(\%)=\frac{\text { Exchangeable } \mathrm{H}}{\text { ECEC }} \times 100 \%
\end{aligned}
$$

\begin{tabular}{|c|c|c|c|c|c|c|c|c|c|c|c|c|}
\hline \multirow{2}{*}{ Treatments } & \multicolumn{6}{|c|}{ First cropping } & \multicolumn{6}{|c|}{ Second cropping } \\
\hline & $2^{*}$ & 4 & 6 & 8 & 10 & 12 & 2 & 4 & 6 & 8 & 10 & 12 \\
\hline $\mathrm{AC}$ & $4.5 \mathrm{~b}$ & $4.4 \mathrm{ab}$ & $4.6 \mathrm{~b}$ & $4.8 \mathrm{~b}$ & $4.8 \mathrm{~b}$ & $4.9 \mathrm{~b}$ & $4.6 \mathrm{~b}$ & $4.6 \mathrm{~b}$ & $4.7 b$ & $4.8 \mathrm{bc}$ & $4.7 b$ & $4.8 \mathrm{~b}$ \\
\hline Lime & $4.9 \mathrm{a}$ & $4.7 \mathrm{a}$ & $5.0 \mathrm{a}$ & $5.5 \mathrm{a}$ & $5.1 \mathrm{a}$ & $5.4 \mathrm{a}$ & $4.9 \mathrm{a}$ & $\mathrm{a}$ & $5.1 \mathrm{a}$ & $5.2 \mathrm{a}$ & $5.1 \mathrm{a}$ & $5.4 \mathrm{a}$ \\
\hline NPK & $4.0 \mathrm{c}$ & $4.0 \mathrm{c}$ & $4.2 \mathrm{~d}$ & $4.5 \mathrm{~b}$ & $4.5 \mathrm{c}$ & $4.4 \mathrm{c}$ & $4.3 \mathrm{~b}$ & $4.3 \mathrm{c}$ & $4.2 \mathrm{c}$ & $4.4 \mathrm{c}$ & $4.2 \mathrm{c}$ & $4.4 \mathrm{~b}$ \\
\hline C $\quad$ + SSP & $4.2 \mathrm{ab}$ & $4.2 \mathrm{bc}$ & $4.3 \mathrm{~cd}$ & $4.8 \mathrm{~b}$ & $4.6 \mathrm{c}$ & $4.7 \mathrm{c}$ & $4.4 \mathrm{~b}$ & $4.3 \mathrm{~b}$ & $4.6 \mathrm{~b}$ & $4.6 \mathrm{bc}$ & $4.4 \mathrm{bc}$ & $4.6 \mathrm{~b}$ \\
\hline $\mathrm{SSP}+\mathrm{GL}$ & $4.5 \mathrm{~b}$ & $4.4 \mathrm{ab}$ & $4.5 \mathrm{bc}$ & $4.7 \mathrm{~b}$ & $4.6 \mathrm{bc}$ & $4.7 \mathrm{c}$ & $4.6 \mathrm{~b}$ & $4.6 \mathrm{~b}$ & $4.6 \mathrm{~b}$ & $4.8 \mathrm{~b}$ & $4.5 \mathrm{~b}$ & $4.8 \mathrm{~b}$ \\
\hline
\end{tabular}

Cowpea yield parameters were also determined during both cropping seasons.

\section{Statistical Analysis}

The soil and plant data collected were subjected to Analysis of Variance using Genstat statistical

Table 2. Effects of chemical fertilizers and lime on soil $\mathrm{pH}$ in Itagunmodi soil series at different weeks after sowing.

Means followed by the same letter(s) in the same column are not significantly different by DMRT at $p<0.05$. $\mathrm{C}=\mathrm{Control}, \mathrm{SSP}=$ Single super phosphate, $\mathrm{GL}=$ Gliricidia sepium leaves. ${ }^{*}$ weeks after sowing. 
Table 3. Liming efficiencies (\%) of the chemical fertilizers in an acidic soil at different weeks after sowing.

\begin{tabular}{|c|c|c|c|c|c|c|c|c|c|c|c|c|}
\hline \multirow[b]{2}{*}{ Treatments } & \multicolumn{6}{|c|}{ First cropping } & \multicolumn{6}{|c|}{ Second cropping } \\
\hline & $2^{*}$ & 4 & 6 & 8 & 10 & 12 & 2 & 4 & 6 & 8 & 10 & 12 \\
\hline $\mathrm{C}$ & 0 & 0 & 0 & 0 & 0 & 0 & 0 & 0 & 0 & 0 & 0 & 0 \\
\hline Lime & 100 & 100 & 100 & 100 & 100 & 100 & 100 & 100 & 100 & 100 & 100 & 100 \\
\hline NPK & -125 & -133 & -100 & -43 & -100 & -100 & -100 & -43 & -125 & -100 & -125 & -67 \\
\hline Urea+SSP & -75 & -67 & -75 & 0 & -67 & -40 & -67 & -43 & -25 & -50 & -75 & -33 \\
\hline $\mathrm{SSP}+\mathrm{GL}$ & 0 & 0 & -25 & -14 & -67 & -40 & 0 & 0 & -25 & 0 & -50 & 0 \\
\hline
\end{tabular}

$\mathrm{C}=\mathrm{Control}, \mathrm{SSP}=$ Single super phosphate, $\mathrm{GL}=$ Gliricidia sepium leaves. ${ }^{*}$ weeks after sowing.

Table 4. Aluminum, hydrogen and acidity saturation percentages in chemical fertilizer and lime treated acidic soil at different weeks after sowing.

\begin{tabular}{|c|c|c|c|c|c|c|c|c|c|}
\hline \multirow[b]{2}{*}{ Treatments } & \multicolumn{3}{|c|}{$\begin{array}{c}\text { Aluminum saturation } \\
(\%)\end{array}$} & \multicolumn{3}{|c|}{ Hydrogen saturation $(\%)$} & \multicolumn{3}{|c|}{$\begin{array}{c}\text { Acidity saturation } \\
(\%)\end{array}$} \\
\hline & $4^{*}$ & 12 & 24 & 4 & 12 & 24 & 4 & 12 & 24 \\
\hline $\mathrm{C}$ & $8.5 \mathrm{a}$ & $8.4 \mathrm{a}$ & $7.8 \mathrm{a}$ & $45.9 \mathrm{a}$ & $44.3 \mathrm{~b}$ & $49.0 \mathrm{a}$ & $54 \mathrm{a}$ & $53 \mathrm{~b}$ & $57 \mathrm{a}$ \\
\hline Lime & $8.8 \mathrm{a}$ & $0.8 \mathrm{~d}$ & $2.9 \mathrm{~b}$ & $31.8 \mathrm{~b}$ & $18.63 \mathrm{c}$ & $27.9 \mathrm{~d}$ & $41 \mathrm{~b}$ & $19 \mathrm{~d}$ & $31 \mathrm{~d}$ \\
\hline NPK & $9.4 \mathrm{a}$ & $7.4 \mathrm{bc}$ & $9.1 \mathrm{a}$ & $50.6 \mathrm{a}$ & $58.5 \mathrm{a}$ & $38.6 \mathrm{~b}$ & $60 \mathrm{a}$ & $66 \mathrm{a}$ & $48 \mathrm{~b}$ \\
\hline Urea+SSP & $10.5 \mathrm{a}$ & $10.6 \mathrm{a}$ & $4.6 \mathrm{~b}$ & $21.0 \mathrm{c}$ & $13.0 \mathrm{~d}$ & $34.0 \mathrm{c}$ & $32 \mathrm{c}$ & $24 \mathrm{c}$ & $38 \mathrm{c}$ \\
\hline $\mathrm{SSP}+\mathrm{GL}$ & $9.5 \mathrm{a}$ & $5.3 \mathrm{c}$ & $2.6 \mathrm{~b}$ & $23.9 \mathrm{bc}$ & $16.3 \mathrm{~cd}$ & $20.4 \mathrm{e}$ & $33 \mathrm{c}$ & $22 \mathrm{~cd}$ & $23 \mathrm{c}$ \\
\hline
\end{tabular}

Means followed by the same letter(s) in the same column are not significantly different by DMRT at $p<0.05$. C=

Control, $\mathrm{SSP}=$ Single super phosphate, $\mathrm{GL}=$ Gliricidia sepium leaves. ${ }^{*}$ weeks after sowing.

package ( $8^{\text {th }}$ edition) and the difference of means among the treatments were analyzed using Duncan's Multiple Range Test at 5\% probability level.

\section{RESULTS AND DISCUSSION}

\section{Soil Physical and Chemical Characteristics}

The soil is strongly acidic with $\mathrm{pH} 4.8$. Available $\mathrm{P}$ (3.6 mg kg-1), organic carbon $\left(13.2 \mathrm{~g} \mathrm{~kg}^{-1}\right)$ and exchangeable $\mathrm{Ca}\left(0.98 \mathrm{cmol} \mathrm{kg}^{-1}\right)$ are below the critical concentrations for southwestern Nigeria soils. Exchangeable acidity is rather high $\left(2.1 \mathrm{cmol} \mathrm{kg}^{-1}\right)$. The texture of the soil is sandy clay loam (Table 1).

\section{Soil pH and Liming Efficiencies of Chemical Fertilizers in an Acidic Soil}

Lime application significantly increased soil $\mathrm{pH}$ compared to control (C) and chemical fertilizer treatments during both croppings (Table 2). The NPK and Urea+SSP significantly reduced the soil $\mathrm{pH}$ below the $\mathrm{C}$ treatment while $\mathrm{SSP}+\mathrm{GL}$ resulted in $\mathrm{pH}$ values similar to $\mathrm{C}$. Soil $\mathrm{pH}$ across all treatments peaked at 8 weeks after sowing (WAS) during both croppings. Slightly higher soil $\mathrm{pH}$ values were observed across all treatments during the second cropping. All the chemical fertilizers tested acidified the soil (Table 3). Negative liming efficiency values were consistently recorded at sampling times. The Urea+SSP at 8 WAS and SSP+GL at 2 and 4 WAS and 2, 4 and 8 WAS during the first and second cropping respectively gave $0 \%$ liming efficiency values. The NPK was the most severe in removing basic ions from the soil with liming efficiency values of $-133 \%$ and $-125 \%$ in the first and second cropping, respectively.

\section{Aluminum, Hydrogen and Acidity Saturation Percentages in Chemical Fertilizer and Lime Treated Acidic Soil}

Lime and chemical fertilizer treatments initially increased $\mathrm{Al}$ saturation above $5 \%$ prior to cropping (Table 4). Lime and SSP+GL however drastically reduced $\mathrm{Al}$ saturation at week 12 and 24, while Urea + SSP decreased Al saturation at week 24 . The NPK treatment consistently increased Al saturation during all the observation weeks. Conversely, all the treatments except NPK at week 4 and 12 resulted in $\mathrm{H}$ saturation values that are generally below the control (C) treatment. The Urea $+\mathrm{SSP}$ and SSP $+\mathrm{GL}$ treatments resulted in $\mathrm{H}$ saturation values lower than lime treatment at week 12 and 24, respectively. The 
Table 5. Calcium, magnesium and potassium saturation percentages in chemical fertilizer and lime treated acidic soil at different weeks after sowing.

\begin{tabular}{|c|c|c|c|c|c|c|c|c|c|}
\hline \multirow{2}{*}{ Treatments } & \multicolumn{3}{|c|}{$\begin{array}{c}\text { Calcium saturation } \\
(\%)\end{array}$} & \multicolumn{3}{|c|}{$\begin{array}{c}\text { Magnesium saturation } \\
(\%)\end{array}$} & \multicolumn{3}{|c|}{$\begin{array}{c}\text { Potassium saturation } \\
(\%)\end{array}$} \\
\hline & $4^{*}$ & 12 & 24 & 4 & 12 & 24 & 4 & 12 & 24 \\
\hline $\mathrm{C}$ & $25 \mathrm{~b}$ & $31 \mathrm{c}$ & $29 d$ & $13.5 \mathrm{~b}$ & $11.7 \mathrm{c}$ & $11.4 \mathrm{~b}$ & $4.5 \mathrm{~b}$ & $2.8 \mathrm{c}$ & $2.7 \mathrm{~b}$ \\
\hline Lime & $43 \mathrm{a}$ & $61 \mathrm{a}$ & $54 \mathrm{~d}$ & $11.9 \mathrm{~b}$ & $13.4 \mathrm{~b}$ & $11.0 \mathrm{~b}$ & $3.5 \mathrm{c}$ & $3.2 \mathrm{~b}$ & $2.4 \mathrm{~b}$ \\
\hline NPK & $25 \mathrm{~b}$ & $21 \mathrm{~d}$ & $30 \mathrm{~d}$ & $9.9 \mathrm{c}$ & $8.3 \mathrm{~d}$ & $14.6 \mathrm{a}$ & $3.6 \mathrm{c}$ & $2.2 \mathrm{~d}$ & $4.9 \mathrm{a}$ \\
\hline Urea+SSP & $45 \mathrm{a}$ & $51 \mathrm{~b}$ & $42 \mathrm{c}$ & $16.1 \mathrm{a}$ & $17.0 \mathrm{a}$ & $13.5 \mathrm{a}$ & $4.6 \mathrm{~b}$ & $3.4 \mathrm{~b}$ & $3.5 \mathrm{ab}$ \\
\hline $\mathrm{SSP}+\mathrm{GL}$ & $41 \mathrm{a}$ & $52 \mathrm{~b}$ & $59 \mathrm{a}$ & $16.6 \mathrm{a}$ & $17.3 \mathrm{a}$ & $13.7 \mathrm{a}$ & $5.2 \mathrm{a}$ & $4.0 \mathrm{a}$ & $2.5 \mathrm{~b}$ \\
\hline
\end{tabular}

Means followed by the same letter(s) in the same column are not significantly different by DMRT at $p<0.05$. C = Control, $\mathrm{SSP}=$ Single super phosphate, $\mathrm{GL}=$ Gliricidia sepium leaves. ${ }^{*}$ weeks after sowing.

Table 6. Base saturation percentage and available $\mathrm{P}$ concentrations in chemical fertilizer and lime treated acidic soil at different weeks after sowing.

\begin{tabular}{lccccccc}
\hline & \multicolumn{3}{c}{ Base Saturation $(\%)$} & & \multicolumn{3}{c}{ Available P $(\mathrm{mg} / \mathrm{kg})$} \\
\cline { 2 - 4 } \cline { 6 - 8 } Treatments & $4^{*}$ & 12 & 24 & & 4 & 12 & 24 \\
\hline C & $46 \mathrm{c}$ & $47 \mathrm{c}$ & $43 \mathrm{e}$ & & $4.9 \mathrm{~b}$ & $5.9 \mathrm{~b}$ & $2.2 \mathrm{c}$ \\
Lime & $59 \mathrm{~b}$ & $81 \mathrm{a}$ & $69 \mathrm{~b}$ & & $6.0 \mathrm{~b}$ & $6.3 \mathrm{~b}$ & $2.7 \mathrm{c}$ \\
NPK & $40 \mathrm{c}$ & $34 \mathrm{~d}$ & $52 \mathrm{~d}$ & & $12.0 \mathrm{a}$ & $14.5 \mathrm{a}$ & $9.7 \mathrm{~b}$ \\
Urea+SSP & $68 \mathrm{a}$ & $76 \mathrm{~b}$ & $62 \mathrm{c}$ & & $10.7 \mathrm{a}$ & $13.2 \mathrm{a}$ & $9.8 \mathrm{~b}$ \\
SSP+GL & $67 \mathrm{a}$ & $78 \mathrm{ab}$ & $77 \mathrm{a}$ & & $10.7 \mathrm{a}$ & $13.5 \mathrm{a}$ & $10.8 \mathrm{a}$ \\
\hline
\end{tabular}

Means followed by the same letter(s) in the same column are not significantly different by DMRT at $p<0.05 . \mathrm{C}=$ Control, $\mathrm{SSP}=$ Single super phosphate, $\mathrm{GL}=$ Gliricidia sepium leaves. ${ }^{*}$ weeks after sowing.

cumulative effect of $\mathrm{Al}$ and $\mathrm{H}$ saturations was depicted by acidity saturation percentage (ASP). The NPK treatment resulted in the highest ASP values at week 4 and 12 and $C$ treatment at week 24. Lime and SSP+GL, however, resulted in the least ASP values at week 12 and 24, respectively.

\section{Calcium, Magnesium and Potassium Saturation Percentages in Chemical Fertilizer And Lime Treated Acidic Soil}

Lime and chemical fertilizer treatments (except NPK fertilizer) significantly increased calcium and magnesium saturation percentages above the $\mathrm{C}$ treatment (Table 5). The Urea+SSP and $\mathrm{SSP}+\mathrm{GL}$ treated plots had similar calcium saturation values at week 4 and 12. However, $\mathrm{SSP}+\mathrm{GL}$ treatment resulted in the highest calcium saturation across all treatments at week 24 . Magnesium saturation remained the same at week 24 in all the chemical fertilizer plots with values above $\mathrm{C}$ and lime treatments. Potassium saturation decreased significantly across all treatments below the initial $5 \%$ prior to cropping, except that in $\mathrm{SSP}+\mathrm{GL}$ at week 4.
Base Saturation Percentage and Available $P$ Concentrations in Chemical Fertilizer and Lime Treated Acidic Soil

All the treatments tested (except NPK at week 4 and 12) increased base saturation above $48 \%$ prior to cropping (Table 6). Treatment SSP+GL however resulted in the highest base saturation at week 4 and 24 compared to lime treatment. Available $\mathrm{P}$ increased significantly across all the chemical fertilizers tested compared to lime and $\mathrm{C}$ treatments. Available $\mathrm{P}$ concentrations were generally higher at week 4 and 12 across all treatments. All the chemical fertilizers resulted in similar available $P$ concentrations at week 12 , while $\mathrm{SSP}+\mathrm{GL}$ resulted in the highest available P at week 24.

\section{Total Nitrogen and Organic Carbon Concentrations in Chemical Fertilizer and Lime Treated Acidic Soil}

Lime and chemical fertilizers generally increased total nitrogen in the soil compared to $C$ treatment (Table 7). The soil nitrogen contents in the lime treatment were initially higher at week 4 and 12, 
Table 7. Total nitrogen and organic carbon contents in chemical fertilizer and lime treated acidic soil at different weeks after sowing.

\begin{tabular}{lccccccc}
\hline & \multicolumn{3}{c}{ Total nitrogen $\left(\mathrm{g} \mathrm{kg}^{-1}\right)$} & & \multicolumn{3}{c}{ Organic carbon $\left(\mathrm{g} \mathrm{kg}^{-1}\right)$} \\
\cline { 2 - 4 } \cline { 7 - 9 } Treatments & $4^{*}$ & 12 & 24 & & 4 & 12 & 24 \\
\hline C & $1.19 \mathrm{c}$ & $1.24 \mathrm{c}$ & $1.15 \mathrm{e}$ & & $11.6 \mathrm{~d}$ & $11.9 \mathrm{~b}$ & $12.3 \mathrm{a}$ \\
Lime & $1.35 \mathrm{a}$ & $1.40 \mathrm{a}$ & $1.17 \mathrm{~d}$ & & $13.4 \mathrm{a}$ & $13.9 \mathrm{a}$ & $11.9 \mathrm{a}$ \\
NPK & $1.25 \mathrm{~b}$ & $1.20 \mathrm{~d}$ & $1.20 \mathrm{c}$ & & $12.4 \mathrm{~b}$ & $11.9 \mathrm{~b}$ & $11.0 \mathrm{~b}$ \\
Urea+SSP & $1.29 \mathrm{~b}$ & $1.30 \mathrm{~d}$ & $1.24 \mathrm{~b}$ & & $13.4 \mathrm{ab}$ & $13.8 \mathrm{a}$ & $12.3 \mathrm{a}$ \\
SSP+GL & $1.28 \mathrm{~b}$ & $1.40 \mathrm{a}$ & $1.30 \mathrm{a}$ & & $12.6 \mathrm{ab}$ & $13.9 \mathrm{a}$ & $12.0 \mathrm{a}$ \\
\hline
\end{tabular}

Means followed by the same letter(s) in the same column are not significantly different by DMRT at $p<0.05$. $\mathrm{C}=\mathrm{Control}, \mathrm{SSP}=$ Single super phosphate, $\mathrm{GL}=$ Gliricidia sepium leaves. ${ }^{*}$ weeks after sowing.

Table 8 . Cowpea yield parameters as affected by chemical fertilizer and lime applications in an acidic soil.

\begin{tabular}{|c|c|c|c|c|c|c|}
\hline \multirow{2}{*}{ Treatments } & \multicolumn{2}{|c|}{$\begin{array}{l}\text { Grain yield } \\
\left(\mathrm{kg} \mathrm{ha}^{-1}\right)\end{array}$} & \multicolumn{2}{|c|}{$\begin{array}{l}\text { Dry shoot weight } \\
\left(\mathrm{kg} \mathrm{ha}^{-1}\right)\end{array}$} & \multicolumn{2}{|c|}{$\begin{array}{c}\text { Harvest index } \\
(\%)\end{array}$} \\
\hline & $1^{*}$ & 2 & 1 & 2 & 1 & 2 \\
\hline $\mathrm{C}$ & $465 \mathrm{~b}$ & $165 \mathrm{~b}$ & $789 c$ & $496 \mathrm{c}$ & $37.1 \mathrm{ab}$ & $24.8 \mathrm{c}$ \\
\hline Lime & $1043 \mathrm{a}$ & $409 a b$ & $1084 \mathrm{c}$ & $848 \mathrm{~b}$ & $49.5 \mathrm{a}$ & $32.6 \mathrm{ab}$ \\
\hline NPK & $980 \mathrm{a}$ & $738 \mathrm{a}$ & $2780 \mathrm{a}$ & $1280 \mathrm{a}$ & $26.1 \mathrm{~b}$ & $35.2 \mathrm{ab}$ \\
\hline Urea+SSP & $869 \mathrm{a}$ & $606 a b$ & $1988 \mathrm{~b}$ & $645 \mathrm{bc}$ & $31.3 \mathrm{~b}$ & $45.7 \mathrm{a}$ \\
\hline $\mathrm{SSP}+\mathrm{GL}$ & 939 a & $456 a b$ & $2310 \mathrm{ab}$ & $487 \mathrm{c}$ & $29.2 \mathrm{~b}$ & $48.7 \mathrm{a}$ \\
\hline
\end{tabular}

Means followed by the same letter ( $\mathrm{s}$ ) in the same column are not significantly different by DMRT at $p<0.05$. $\mathrm{C}=\mathrm{Control}, \mathrm{SSP}=$ Single super phosphate, $\mathrm{GL}=$ Gliricidia sepium leaves. ${ }^{*}$ cropping season.

which later decreased at week 24 . Of all the chemical fertilizers, only SSP+GL promoted increases in total nitrogen at week 12 above $1.3 \mathrm{~g} \mathrm{~kg}^{-1}$ prior to cropping, resulting in the highest soil nitrogen content at week 24. Lime, Urea + SSP and SSP + GL treatments resulted in similar soil organic carbon content at week 12 and 24. Conversely, NPK treatment consistently resulted in the lowest soil organic carbon content with the lowest content was observed at week 24 compared to $\mathrm{C}$ treatment.

\section{Effects of Chemical Fertilizers and Lime on Yield Parameters of Cowpea in an Acidic Soil}

Chemical fertilizers enhanced cowpea yield parameters compared to lime treated plots in both cropping seasons (Table 8). Plots treated with NPK fertilizer had highest grain yield, although not significantly different from others. This was followed closely by SSP + GL. The NPK fertilizer application resulted in the highest shoot dry weight in both seasons. The highest Harvest index (HI) was found in the lime treated plots during the first season and in SSP +GL plots in the second cropping season.

\section{Discussion}

Soil $\mathrm{pH}$ reduced drastically under chemical fertilizer treatments from the initial 4.8 to 4.0. The acidulating potentials of the chemical fertilizers tested were well depicted by negative liming efficiency values recorded. The higher the liming efficiency value in the negative direction the higher the acidulating potential (Anetor and Akinrinde 2007). Higher acidulating potential depicts higher intensity of basic cations removal and or acidic cation addition to soils. Chemical fertilizers especially the nitrogen based fertilizers are known for nitrification reaction, which has been reported as the major factor contributing to their acidulating property (Lungu and Dynoodt 2008; Tan 2011). It involves the transformation of $\mathrm{NH}_{4}^{+}$into $\mathrm{NO}_{3}{ }^{-}$ions. This reaction is accompanied by the release of $\mathrm{H}^{+}$ions that acidify the soils. The resultant product of nitrification- $\mathrm{NO}_{3}^{-}$ is highly mobile in soils and carries along with it alkaline cations as it moves through the soil profile. The result of which is depletion of basic cations and increased acidity in the top soil. 
Liming efficiency has been used to predict the acidity contribution of tested materials relative to a conventional liming material (Anetor and Akinrinde, 2007). All the chemical fertilizers tested contributed acidity to the soils. This result corroborates the findings of Anetor and Akinrinde (2007) on their assessment of liming efficiencies of common chemical fertilizers. Single super phosphate (SSP) based chemical fertilizers, however, gave zero and positive values at most sampling time. The implication of this is that SSP fertilizer has some reserve basicity in it since calcium is a nutrient component in SSP fertilizer. The urea in Urea+SSP treatment was responsible for its lower liming efficiencies compared to $\mathrm{SSP}+\mathrm{GL}$. Use of organic nitrogen source such as Gliricidia sepium leaves seems to benefit the soil used in the current study. Gliricidia sepium leaves combined with single superphosphate was responsible for neither removal nor addition of basicity. The NPK fertilizer was the most severe in contributing soil acidification among the chemical fertilizers under study. It removed up to $133 \%$ of basicity in the soil. The term acidification efficiency order than liming efficiency better explains the effects of these chemical fertilizers on soil reactions of the soil studied.

The rate of acidification of the soil by the chemical fertilizers especially NPK fertilizer was influenced by cropping season. The first and second croppings fell into the wet and dry seasons, respectively. The calcium saturation percentages across all the chemical fertilizer treated plots were below $65 \%$, which is considered suitable for the cultivation of most arable crops (Eckert 1987). Losses of basic cations especially calcium through leaching and percolating water have been reported (Wong et al. 1992; Mauro et al. 2002). Calcium losses through leaching during the wet season coupled with its comigration with $\mathrm{NO}_{3}^{-}$and increasing exchangeable acidity explain the higher acidulating property in NPK fertilizer treated soil. Similar comigration of calcium along with $\mathrm{NO}_{3}^{-}$in urea treated soil had been reported (Wong et al.1992). The generally lower calcium, magnesium, potassium and base saturations in NPK treated plots at the end of the first cropping (week 12) than the second cropping (week 24) depict higher susceptibility of basic cations to losses under NPK fertilizer compared to other chemical fertilizer treatments during the wet season.

Cultivation process and chemical fertilizer applications resulted in increased aluminum saturation above $5 \%$ prior to its cultivation. The NPK fertilizer treated plots maintained values consistently above the initial $5 \%$. The increases in aluminum and hydrogen saturation concentrations in the unamended soil (C) at the end of the second cropping depict continuous cultivation process alone on this soil can encourage increasing exchange of aluminum and hydrogen ions from the soil exchange sites into soil solution. Continuous cropping without replacement of nutrients taken up by plants contributes largely to soil nutrient (basic cations, organic carbon and available phosphorus) mining. This phenomenon is considered has a major anthropogenic factor contributing to soil acidification (Franklin 2012). Reduction in basic cation concentrations is associated with increasing acidic cations, $\mathrm{Al}$ solubility and overall reduction in soil reaction (Kopittke and Menzies 2007). More influence of cultivation of these soils without external nutrient sources on acidity saturation is more pronounced in wet season (week 12).

Conversely, acidity saturation was below the initial $53 \%$ in all the chemical fertilizer treatments, except that in NPK fertilizer treatment. This result indicates slight differences in the acidification efficiencies of NPK and SSP fertilizers. The mechanisms in which NPK fertilizer acidifies the soil studied include increased aluminum and acidity saturation and decreased calcium and magnesium saturations. Increased aluminum saturation was the major reaction pathway for soil acidification by SSP fertilizer in the soil. Single super phosphate fertilizer especially when combined with Gliricidia sepium leaves added the calcium and magnesium in the soil pool. Interestingly, it contributed greatly to improve base saturation in the soil compared to the conventional lime treatment. The Gliricidia sepium leaves was important in consuming the protons released in to the soil by the chemical fertilizers. This encourages maintaining the soil $\mathrm{pH}$ at what it was at the point of chemical fertilizer application (Tan 2011).

\section{CONCLUSIONS}

The understanding of the reactions of chemical fertilizers in low activity clay mineral tropical soils is of importance with the current increase in their use in Nigeria. Results of current study revealed all the chemical fertilizers tested to contribute significantly to acidification of the soil studied in the order of NPK 15:15:15 > Urea+SSP > SSP+GL. The acidification mechanism of these chemical fertilizers differs. The mechanism involved in the acidification of the soil by NPK 15:15:15 included increased aluminum and acidity saturations and decreased calcium and magnesium saturations, 
while increased in aluminum saturation was the major reaction pathway for soil acidification by single superphosphate. Present works also show higher acidulating potentials of NPK 15:15:15 during wet/ rain season than dry season. Continuous cropping of the soil studied without replacement of nutrients taken up by plants deplete the soil more of its basic cations, organic carbon and available phosphorus. The use of these chemical fertilizers on the soil studied should be done with other soil management practices such as proper erosion control, coapplication of the chemical fertilizers with liming material and organic materials source such as the Gliricidia sepium leaves tested in this work. The Gliricidia sepium leaves were important in consuming the protons released into the soil by the chemical fertilizers. This encourages maintaining the soil $\mathrm{pH}$ at what it was at the point of chemical fertilizer application.

\section{ACKNOWLEDGEMENTS}

The authors appreciate the assistance of the technologists at the Soil Chemistry Laboratory of the Department of Agronomy, University of Ibadan and that of the International Institute of Tropical Agriculture, Nigeria for the analysis of the soil samples.

\section{REFERENCES}

Amlinger F, S Peyr, J Geszti, P Dreher, K Weinfurtberand, and S Nortcliff. 2007. Beneficial effects of compost application on fertility and productivity of soils. Federal Ministry for Agriculture and Forestry, Environment and Water Management. Lebensministerium.at. 173p.

Anetor MO and EAAkinrinde. 2007. Lime effectiveness of some fertilizers in a tropical acid alfisol. J Cent Eur Agric 8: 17-24.

Bouyoucos GJ. 1962. Hydrometer method improved for making particle size analysis of soils. Agron J 54: 464-465.

Cassio HA Jr, M Takashi and FL Andre. 2003. Exchangeable aluminum evaluation in acid soils. Scientia Agricola. 60. Retrieved June 8, 2012 from http://dx.doi.org/10.1590/50103.

Eckert DJ. 1987. Soil test interpretations: basic cation saturation ratios and sufficiency levels. In: Soil Testing: Sampling, Correlation, Calibration and Interpretation. Brown, J.R. Ed. Soil Science Society of America, Maidison, Wisconsin pp.53-64.

Fageria NK, AB Dos-Santos and MF Moraes. 2010. Influence of urea and ammonium sulfate on soil acidity indices in lowland rice production. Communications in Soil Science and Plant Analysis 41: $1565-1575$.
FAO 2000. The state of food and agriculture, lessons from the past 50 years. Food and Agricultural organization of the United State.

FAO 2006. The state of food security in the world. Eradicating world hunger - taking stock ten years after the world food summit. Food and Agricultural organization of the United State. Viale delle Termedi Caracalla, 00153 Rome Italy.

Franklin ON. 2012. Ameliorating soil acidity in Ghana: A concise review of approaches. ARPN J Sci Tech 2: special issue, ICESR. 1-9 pp.

Gaisseler D and Scow KM. 2014. Does long term use of mineral fertilizers affects the soil microbial biomass? Soil Biol Biochem 75: 54-63.

International Institute of Tropical Agriculture. 1978. Selected methods for soil and plant analysis. Manual series No. 1. $2^{\text {nd }}$ edition, pp. 1-24.

Kopittke PM and NW Menzies. 2007. A review of the use of the basic cation saturation ratio and the "Ideal Soil". Soil Sci Soc Am J 71: 259 - 265.

Lungu OI and RF Dynoodt. 2008. Acidification from long term use of urea and its effects on selected soil properties. Afr J Food, Agr, Nutr Develop 8: 63-76.

Mauro WO, COT Paulo, EBT Antonio and M Jeferson. 2002. Leaching of nitrogen, potassium, calcium and magnesium in sandy soil cultivated with sugarcane. Pesquisa Agropecuaria Brasileira 37.6. on line version assessed at http://dx.doi.org/10.1590/S0100204X2002000600016 on 10th October 2015.

Mclean EO. 1965. Aluminum. In: CABlack (ed). Methods of soil analysis. Part 2. Chemical methods. Madison. ASA $978-998$ pp.

Murphy J and JP Riley. 1962. A modified single solution method for the determination of phosphate in natural waters. Analy Chim Acta 27: 31-36.

Oke SA, MN Tijani and OM Adeyemo. 2013. Influence of bedrock weathering of the shallow ground water system around felsic metasediment and amphibolites of the Ilesha schist belt. Transnatl $J$ Sci Tech 3: 36-53.

Oyeyiola YB, JAI Omueti, N Njoku and E Oyekanmi. 2014. Assessment of Liming Potentials of Phosphocompost and Synthetic Fertilizers in an Acidic Alfisol for Cowpea Production. J Plant Pest Sci 1: 128-137.

Oyeyiola YB, JAI Omueti and GO Kolawole. (2015). Effects of phosphocompost on acidity indices in an acidic soil in Ilesha, southwestern Nigeria. In: G Rahman, TI Olabiyi and VIO Olowe (Eds). Scientific track Proceeding of the $3^{\text {rd }}$ African Organic Conference. Achieving Social and Economic Development through Ecological and Organic Agriculture Alternatives. October 5-9, 2015, Lagos, Nigeria.

Smyth AJ and RF Montgomery.1962. Soils and land use in central western Nigeria. Government Printer, Ibadan.

Tan KH. 2011. Principle of soil chemistry. $4^{\text {th }}$ edition. New York: CRC Press 10- 85 pp.

Wong MT, AC Van der Kruijs and ASR Juo. 1992. Leaching loss of calcium, magnesium, potassium and nitrate derived from soil, lime and fertilizers as influenced by urea applied to undisturbed lysimeters in southeast Nigeria. Fert Res 31:281-289. 